\title{
THE ANXIETIES OF
}

\section{AUTHENTICITY IN POST-2000}

\author{
BRITISH FICTION
}

\section{Daniel Lea}

What might it mean to live an authentic life in the early twentyfirst century? What ethical coordinates would need to be calibrated to enable one to declare her/himself authentically positioned within subjectivity? Despite the imprecations of a profitable sector of the publishing industry that the path to authentic living is lined with tomes preaching self-help and self-realization, late-twentieth-century philosophical accounts on the subject are altogether more skeptical about the interdependence of selfhood and authenticity. The "postdeconstructive subject"(Critchley 51) that has risen to prominence since the 1960's linguistic turn is characterized more by fragmentation and exteriority than by coalescence around a core and transcendent inner substance. Indeed, the very notion of an authentic subjectivity begs the quotation marks that I will refuse to apply in this essay, bringing with it overtones of an unreflective universalism that poststructuralism, feminism, postcolonialism and postmodernism have trained critics in the humanities to distrust. Yet, as we enter the second decade of the twenty-first century, the reemergence of authenticity as an ethical marker of contemporary subjectivity is gaining significant traction.

At the level of daily Western praxis, the growing popularity of organic consumerism, ecological politics, lifestyles more attuned to natural processes and nostalgia chic-all part of what David Boyle calls

MFS Modern Fiction Studies, Volume 58, number 3, Fall 2012. Copyright (C) for the Purdue Research Foundation by the Johns Hopkins University Press. All rights to reproduction in any form reserved. 
the "New Realism" (15) - speak of an appetite, especially among the middle classes, for the genuine and unvarnished. We have entered what Charles Taylor describes as "the Age of Authenticity" (Secular 473). We are feeling Alain Badiou's "passion for the real" (39) and experiencing David Shields's "reality hunger." Taylor characterizes the current ethic of authenticity as the product of the twin movements toward individualism and away from social communitarianism in the second half of the twentieth century, movements embedded by the socio-political neoliberalism of the Regan-Thatcher era. Since the 1960s:

we see a steady spread of what I have called the culture of "authenticity." I mean the understanding . . . that each one of us has his/her own way of realizing our humanity, and that it is important to find and live out one's own, as against surrendering to conformity with a model imposed on us from outside, by society, or the previous generation, or religious or political authority. (Secular 475)

This imperative to ethical self-determination, to the deliberate rejection of socially symbolic systems in favor of self-discovered or intuited models of being, has brought about a "simplified expressivism" whose primary tenet is to "find yourself, realize yourself, release your true self" (Secular 475). The reduction of a complex existentialist fundamental to a solipsistic mantra of self-becoming has led, for David Shields, to a paradoxical self-dispossession. For him, the artistic expression of this philosophy is characterized less by plenitude than by disappointment: "we've lost something along the way and are going back to try to find it, but we don't know what that thing is. . . . We're clinging to anything that seems 'real' or organic or authentic" (90).

Postmodern culture, with its fetishization of the mash-up, the pastiche, and the recombinant, mirrors the contemporary vision of subjectivity as performative and protean, and Shields's anxiety is that all the emphasis on being oneself-in an aesthetic environment where to be oneself is to be an imitation of others-produces a bewildering double-think that achieves exactly the opposite of the expressivist ideal. To be oneself without being one self calls the whole ideal of expressivism into question. Given the uncoupling of self-understanding from the validating structures of religious discipline and social collectivism, how one goes about locating an authentic hub, and testing that against any model other than a subjective pathos, is philosophically problematic. And yet, a generation after the Linguistic Turn, the lure of the authentic as an absolute mode of being has not only not diminished, but has reasserted itself as an insistent trope of contemporary lived and aesthetic practice. Taking British fiction 
since 2000 as its focus, this essay will explore the prevalence and diversity of this theme and, through the examination specifically of Tom McCarthy's Remainder and Steven Hall's The Raw Shark Texts, will argue that the current anxiety of authenticity stems from the unresolved tension between the expressivist ethic and the horizon of the postdeconstructive subject.

The idea of the authentic as a quality of the material world has been current throughout British postmodern writing: one need look no further than John Fowles' The French Lieutenant's Woman (1969), Graham Swift's Waterland (1983), Kazuo Ishiguro's The Remains of the Day (1989), or A.S. Byatt's Possession (1990). The ideal of authenticity as a way of living has become increasingly important in the last decade, a period critics such as Steven Connor identify with postmodernism's turn to the ethical. Work like W.G. Sebald's Austerlitz (2001), which dramatizes the reconstitution of a self-congruent life narrative, suggests a closer engagement with the human need to believe in the authentic as an endpoint of personal growth. It is an engagement that is identifiable, in different ways and for different reasons, in texts as diverse as Zadie Smith's White Teeth (2000), Niall Griffith's Sheepshagger (2001), Andrew O'Hagan's Be Near Me (2006), Rachel Cusk's The Bradshaw Variations (2009) and Monica Ali's Untold Story (2011). The implausibility of achieving authenticity in an age of over-sentimentalised celebrity culture is the subject of Will Self's rewrite of Oscar Wilde: Dorian: An Imitation (2002), while Jeannette Winterson's The.Powerbook (2000) suggests that a route toward a fusion of authentic and inauthentic selfhood may be found through the kinds of promiscuous identity exchange made possible by digital communication. The cynicism and technological utopianism of the last two examples are, however, uncharacteristic of recent fiction's striving to marry the desire for the real with the legacy of postmodernism's fascination with the simulacral. That is characterized much more by the work of Hall and McCarthy, where the contemporary conviction in the conditioned and exteriorized nature of identity is counterbalanced by a residual belief in the transtemporal, self-identical subject. The questions that will underpin the discussion of their novels revolve around whether the notion of the authenticas it is understood in existentialist philosophy-can remain relevant beneath the challenge of the decentered subject. Is it possible to accommodate the self-congruent subject with the deconstructed self of postmodernism, and if so, what manner of authenticity could emerge? These questions necessitate a brief explanation of two philosophical models of authentic being that are widely articulated in contemporary culture. 
Lionel Trilling, in his influential account of modernity's engagement with the subject, Sincerity and Authenticity, posits the interpretation of authenticity as "the downward movement through all the cultural superstructures to some place where all movement ends, and begins" (12). He additionally claims that authenticity requires a "strenuous moral experience. . . [an] exigent conception of the self and of what being true to it consists in, and a less acceptant and genial view of the social circumstances of life" (11). This emphasis on a rootedness that demands high standards of moral conduct and a psychological distance from social factors encapsulates three key aspects of the philosophical tradition of authenticity: its belief in the core of agency; its requirement for a moral or ethical dimension; and the potential for conflict between the needs of the individual and the demands of the community. All accounts of authenticity fundamentally revolve around variations of these criteria and disagree to varying degrees on the relative importance of the separate elements. ${ }^{1}$ Though critics agree that authenticity is a by-product of the social and intellectual conditions that gave birth to post-Enlightenment modernity, for the purposes of this essay, I will make the distinction between the older tradition of authenticity that starts with Rousseau, and the more recent post-Nietzschean formulation as a means of determining how they are interpreted in contemporary culture.

At the heart of Romanticism's authentic is what Charles Guignon describes as "the attempt to recover a sense of oneness and wholeness that appears to have been lost with the rise of modernity". The "truth" of the self cannot be accessed through rational contemplation or scientific enumeration, but only "by a total immersion in one's own deepest and most intense feelings" (51). The sine qua non of this view is the foundational integrity of the human self, a fullness that correlates directly and organically to the natural world, but is rent by the submission of its instinct and desire to the communitarian good. Thrown into the service of the other, the Romantic self must, in order to achieve authentic self-understanding and freedom from the imposition of external codes of conduct, reject its duty to others, thereby becoming paradoxically self-alienated. As such, "Hegel says that it has made a step in progress. He puts it that the existence of the self 'on its own account is, strictly speaking, the loss of itself'" (Trilling 38). The forging of an authentic spirit through the uncoupling of conduct from socially received opinion and values entails the active engagement of ethical judgement and responsibility in the shaping of a self, but it presupposes the possibility of a reconstituted whole on the blueprint of a premodern nostalgia. This model of authenticity as a form of biological inheritance is refigured in the twentieth century's understanding of psychological science as an uncovering of 
the palimpsest of influences and intersubjective relations to reveal the dialectic between the subject's drives and instincts. The core tenet of this ideal of authenticity, then, directs us "to realize and be that which you already are, the unique, definitive traits, already there within you" (Guignon 4).

The other significant strand within the tradition of authenticity is summed up for Alessandro Ferrara in the etymological history of the term: "In Greek "authentikós" derives from 'eautón' and 'theto,' where 'theto' is etymologically related to 'thesis.' Thus 'authentic' refers to individuals who 'posit themselves' or, more freely, 'set themselves as a thesis'" (15). As opposed to the biological model of uncovering and nurturing that which already exists beneath a carapace of social conformist values, this construction accentuates the authentic as part of the treatment of the subject as a working negotiation of incessant change and ethical challenge. The authentic individual, by this token, exhibits "the congruency of the well-formed work of art" (Ferrara 10), revealing superstructural integrity in her/his willingness to cohere around a consistent logic of the self instead of a nostalgic longing for an illusory wholeness. The individual who "posits themselves" must necessarily regard her/himself simultaneously as both inner and outer, as a self-constant being generated sui generis, and as a product sculpted from the torrent of public and private experiences that assail them. This project should not be read as the artificial imposition of a fiction of selfhood-such a judgement error would lead one into inauthenticity-but as the process by which one becomes what one is, to paraphrase Nietzsche. While this retrenchment to an apparently pre-given identity indicates Nietzsche's debt to the biological tradition of Rousseau, Jacob Golomb warns against collapsing the two: "To become 'what we are' is not to live according to our so-called 'innate nature,' but to create ourselves freely. To that end we have to know ourselves to distinguish what we can change in ourselves and in the external circumstances that have shaped us [and] we must realize what we have to accept as inevitable" (69). In other words, the way to authenticity is to negotiate the blizzard of living's experiences, feelings and ideas by remaining in touch with the inner life, listening to its dictates and molding our values and beliefs in accord with it. The ethical decisions we might make are of importance primarily for their constancy in support of the project, but there is no single, given way in which the uniqueness of our individuality might express itself-merely a series of challenges that must be overcome in the interests of self-congruence. As Golomb comments: "It follows that within the framework of Nietzschean philosophy we cannot speak about authentic character or self. Authenticity is a predicate not of character or of the self, but merely of acts and pathos" (82). 
These brief explications of the philosophical coordinates of authenticity clearly overlap and have crossfertilized, but both models have currency in the work of Hall and McCarthy where their contradictory imperatives between being and becoming lead ultimately to the flight from subjectivity. The resilience of self-posited authenticity in contemporary writing is hardly surprising, given the Nietzschean inheritance in poststructuralist and postmodern theory and the fashionable skepticism toward the universalising absolutism of any subjectivity, but it is notable that the return of the real in the latetwentieth and twenty-first centuries has brought with it a reengagement with the viability of the biological ideal. Whether the kernel of wholeness can be recuperated, or must always remain chimerical, is as unresolved now as it ever was, but recent writing has evinced the desire for some accommodation of the self-identical and the self-fashioned subjects. Remainder and The Raw Shark Texts-both experimental, post-trauma fictions whose authors have been schooled in the discursive, metapractices of postmodernism-toy with the mutual compatibility of biological and self-posited authenticity, and though neither is ultimately comfortable rescinding the self-reflexivity of the deconstructed subject, neither are they willing to dispense totally with the idea of the irreducible self.

Both novels share a view that the integrity of the individual as autonomous, self-determining agent is tied to a pathos of harmonious being-in-the world. But they equally share the fear that the expression of that agency is problematised by discourses of social and cultural conditioning that shadow each action or ethical choice with the inauthenticity of the precursory echo. Of course, the story of existentialist authenticity from Kierkegaard, Hegel, and Rousseau to Nietzsche, Heidegger, and Sartre has been dominated by anxiety over the deauthenticating effect of social influence, but the current incarnation of the debate is complicated by postmodernism's triumphing of the inauthentic, the fake, the parodic, the reproducible as an aesthetic response to the exhaustion of representation. The central protagonists of both novels are painfully conscious of the provisionality of their places within the symbolic order and are enmeshed in the matrices of representational exchange to such an extent that they struggle to articulate themselves as anything other than reproductions. For McCarthy's unnamed narrator, authenticity can only be experienced as intangibility, the fleeting apperception of a transcendent core not just to selfhood, but also to life itself. His motivating desire is: "to be real-to become fluent, natural, to cut out the detour that sweeps us around what's fundamental to events, preventing us from touching their core: the detour that makes us all second-hand and second-rate" (244). The explicit value judgement in 
the second-rate-ness of inauthenticity implies McCarthy's discomfort with postmodernism's ludic self-reflexivity, and his confidence in a core that renders matters "fundamental" suggests his writing back to older traditions of phenomenology. Hall's Eric Sanderson expresses a similar frustration with the elusiveness of his own internal constancy: "I'd been a flat thing, something I always mistook for a shadow, but maybe the eroding effect of events had begun weathering me out of the ground, revealing new surfaces and edges. Can nothing really be scraped away the same way that something can?" (232). Though the metaphor here is archaeological rather than orbital, Hall articulates the same desire for the "thing" itself, not merely a pathos of subjectivity, but a palpable haecceity.

While Remainder's narrator and Eric Sanderson express a deep-rooted desire for being and acting authentically, and although both locate their nebulous sense of the authentic within the "heroic idea of coinciding with oneself and one's deepest needs or impulses" (Williams 184) that I am affiliating here with the biological tradition, the former locates it primarily as a spatial paradigm, while Hall's character understands it within a linear narrative register. Indeed, for McCarthy, the coincidence with self can only be articulated through the confluence of material and immaterial realms. Recovering the memory of his home in an apartment block is an epiphany of heimlich belonging and intentionality:

Most of all I remembered this: that inside this remembered building, in the rooms and on the staircase, in the lobby and in the large courtyard between it and the building facing with the red roofs with the black cats on them - that in these spaces, all my movements had been fluent and unforced. Not awkward, acquired, second-hand, but natural. Opening my fridge's door, lighting a cigarette, even lifting a carrot to my mouth: these gestures had been seamless, perfect. I'd merged with them, run through them and let them run through me until there'd been no space between us. They'd been real; I'd been real- been without first understanding how to try to be . . . (62)

The concomitance of materiality and experience of self here situates the authentic as a phenomenological quintessence, a compacting of the space between self and thing. The narrator makes the assumption that the authentic is a consummation of external naturalness with a form of internal perceptive flow that transcends the need for contemplation by accessing a state of pure being. The thus-ness of the fridge door, the way that Robert de Niro might light a cigarette, or the crack in the wall plaster that the narrator remembers (and tries to 
recreate) so intimately, speak of an order of veracity and inevitability that he cannot match in the act of living but is continually striving for as a confirmation of his being. In the process of creating the Platonic ideal of his past, the narrator experiences micromoments of perfect convergence where the consciousness of existence falls away, and he is left in a condition of messianic transportation: "Remembering it [the accident] sent a tingling from the top of my legs to my shoulders and right up into my neck. It lasted for just a moment-but while it did I felt not-neutral. I felt different, intense: both intense and serene at the same time. I remember feeling this way very well: standing there, passive, with my palms turned outwards, feeling intense and serene (11)." ."Serene" appears as the descriptor of this embodied authenticity again later in the novel (204), and the image that he projects of himself-static, accepting, with palms turned outwardsuggests both openness to the connectivity of the moment and a Christ-like gesture of entreaty. It is a sensation that he describes elsewhere as a "calm contentedness" (138), and it is in these rare moments of transcendent being, when he feels instrumental to the moment, that he comes closest to achieving a form of authenticity as an experience of immanence.

As the obsessive nature of the narrator's project develops, and as his mental condition deteriorates, the transcendence of the material plane becomes his driving motivation. Two moments stand out in this regard: firstly, when he becomes fascinated by the chores carried out at a small garage, and secondly, when he attempts to recreate what he assumes to be a gangland murder. In the first instance, the seemingly routine task of renewing his car's washer fluid becomes a moment of material commutation when the liquid appears magically to disappear before gushing out of the dashboard. The narrator's transport of delight at this apparent dematerialisation centers on the momentary uncoupling of stuff from the laws of matter; the mundane seems through a process of transubstantiation to have become immaterial, leaving no remainder. The subsequent revelation of the fault in the vehicle's plumbing system repudiates this miracle and throws the narrator back into the state of rational physics that he associates with inauthenticity. The second example reveals his increasing inability to distinguish between enactment and reenactment as he choreographs life's final moments in an attempt to achieve a form of authentic being-toward-death. By reenacting the experience of the victim of a killing as he faces the unavoidability of his demise, the narrator hopes for atranscendence in space to where living and dead matter coincide:

It may have been clumsy to fall from his bike, but in dying besides the bollards on the tarmac he'd done what I 
wanted to do: merged with the space around him, sunk and flowed into it until there was no distance between it and him - and merged too, with his actions, merged to the extent of having no more consciousness of them. He'd stopped being separate, removed, imperfect. . . . Then both mind and actions had resolved themselves into pure stasis. The spot that this had happened on was the ground zero of perfection-all perfection. (184-185)

If one understands the authentic as a pathos of coalescence, then such reenactments are attempts to access the authentic through the profoundly inauthentic process of endless recreation, robbing the moment of its spontaneity through forensic aestheticisation and examination. Analyzing an experience of haecceity in minute detail profoundly dehumanizes and denaturalizes the event, reducing it to its signifying constituents, but it is only in this disarticulation that the narrator is able to identify any transubstantiation between the material and the immaterial. Lying on the ground, imagining the world from the perspective of another, enables his sensation of connectedness not only to the consciousness of another person, but also to the substrata of the material world. The realness for which he strives can be perceived through the slow-motion deconstruction of events, but its quality is fundamentally scenographic and the authenticity attained is always troubled by the taint of a residual inauthenticity.

McCarthy's work with the art and philosophical collective, the International Necronautical Society (INS), has focused on this residual inauthenticity as an indicator of the failure of artistic creation to achieve transcendence. At the heart of McCarthy's interest in the idea of authenticity as it relates to the concerns of the INS is the idea that death is a space beyond the human and yet inextricably underlies the experience of subjectivity and the relationship to representation. The failing of art is its inability to transcend either death or itself. The traumatized repetition that is involved in the creative process, and in the reenactment in which the narrator of Remainder indulges, is circumscribed by the materiality of matter and its attachment to the world of concrete phenomena. The narrator is engaged in a vain attempt to master his self, to be individual rather than dividual, to cohere singularly rather than recognize the constant process of splitting that constitutes subjectivity. His attempts to reconstruct unreliable memories and reenact the coalescence of the sublime moment of individuation all fail in the face of the materiality of matter. There is always "a remainder that remains: a shard, a leftover, a trace, a residual" and this remainder is the "mark of inauthenticity" (Schwenger). The narrator expresses his desire for a totalizing, mystical transcendence in moments such as those discussed above, 
a perfect coincidence of self with un-self, yet in each case, the transcendence is denied-experience is inauthentic because it remains within the phenomenal.From the Necronautical perspective, this failure to transcend becomes the motivating imperative for rejecting singularity and embracing the constant splitting of self into matter. Matter, and its valorization, becomes the focus, and the emphasis on its imperfection the means to articulate the subject's lack of core.

For these reasons, the project enacted in Remainder-that of reconstituting the authentic self through an act of imaginative remembering-dwells in the arena of art and self-fashioning, and might thus be seen to fit more closely within the self-posited model of authenticity proposed earlier. The narrator's conscious and painstaking self-recreation does not negate the possibility of an inner core, nor does it illegitimize the profundity of his epiphanies of belonging, but it does imply that the path to authenticity for the postdeconstructive and posttraumatic subject involves the intricate micromanagement of the aestheticized object of the self. Cleaving the component actions of a self together in the shape of authentic identity requires the ethical constancy, moral alertness, and artistic objectivity that Nietzsche believes crucial to the process of self-overcoming, and Remainder's narratorial figure works hard to batten down the connective elements of his subjectivity. However, the supplementarity that haunts the novel in the forms of remainders, residues, shards, and bits would seem to undermine the possibility of that self-overcoming being productive of a coherent selfhood in the way that Nietzsche imagines.

The remainder-that which cannot be assimilated into the biological or self-posited authentic-is encapsulated in the motif of the figure eight and its correlative to infinity in the symbol $\infty$. This pattern features prominently in the $£ 8.5$ million sum that the narrator receives in compensation for the accident that motivates the narrative and is repeated in various guises throughout the novel. The integrity of the unbroken loop of infinity strongly suggests the perfection of the authenticity that the narrator seeks, a closed circuit that refers to nothing outside itself and yet sustains its own energy. However, the simplicity of the figure eight is complicated by the .5 supplement that attaches itself to his bank account, but also to his psychological make-up: "The eight was perfect, neat: a curved figure infinitely turning back into itself. But then the half. Why had they added the half? It seemed to me so messy, this half: a leftover fragment, a shard of detritus" (9)" The financial settlement is supposed to be the thing that "would make me better, whole, complete" (6), some kind of complement to counterbalance the erasure of the past, and yet he is constantly troubled by the remainder. The .5 is surplus matter that stubbornly will not resolve itself into something whole. 
As the novel draws to its close, the figure is iterated once again as the aeroplane that the narrator and Naz have charted to flee the reenacted-heist-turned-real adopts a pattern of back and forth looping as the narrative rests inconclusively between escape and retribution. This final image of wholeness is undercut, as is every other example in the text, with the failure of transcendence and a pained skepticism toward the possibility of authenticity as anything other than a momentary appearance of self-coherence. Consequently, McCarthy leaves his reader with a disconcerting sense that both models of authenticity are simultaneously plausible and implausible. Where the inherence of biological authenticity fails the test of its own interiority, so self-posited authenticity fails the test of artistic transcendence. And yet neither is dismissed by the novel as a fantasy; indeed, both are presented as somehow irreducibly part of the human condition, without which the concept of subjectivity is fatally impoverished.

McCarthy's uncertainty about the metaphysical credibility of authenticity in the age of the postdeconstructed subject is echoed in Hall's discomfort with the impact of technological homogenization on the status of human uniqueness. A considerably warmer novel than Remainder, The Raw Shark Texts nevertheless displays an anxiety about the meaning of authenticity in the relationship between the human and the machine. Where McCarthy plays with the philosophical landscape of the authentic in the manner of the modernist avant-garde he emulates, Hall's work elicits a genuine anxiety that the subject cannot cohere in the face of digital reproducibility and is consequently threated by obsolescence. Where the objective detachment of McCarthy's anonymous narrator endows his self-projection with a crystallizing security, the metaphysical uncertainty of Eric Sanderson reveals a deep apprehension about the imperialistic assertion of selfhood. Like McCarthy, Hall posits both models of authentic expressivism with which we have been playing, and is seemingly convinced that the interiorized, biological spirit is a nostalgic myth and that the idea of the subject is formed and maintained through the frameworks of information that surround us and the cultural typologies that we mimic. The awareness that the subject is constituted predominantly, and primarily, from the outside suggests an affinity of outlook between Hall and McCarthy, but at the heart of the narrative is Eric's faith that the inside means something; there is a faith here despite the evidence. The kernel of the self cannot be so categorically dismissed.

Eric Sanderson-or, the Second Eric Sanderson, as he is consistently described in the novel-is a simulacrum, a shadow of the first Eric who has disappeared and yet relates gnomically with his alterego through letters and coded communiqués, designed to keep him 
from the grasp of the conceptual Thought Shark who may, or may not have, consumed the first Eric. Crucially, then, the Second Eric is always symbolically posthumous, trailing his antecedent in search of answers. The mental fugue that has wiped his memory at the narrative's opening positions him as a tabula rasa requiring inscription to locate himself within his own subjectivity. Yet, Eric's selfhood is always provisional, contingent on filling the knowledge gaps left by the first, and implicitly authentic, Eric. Only by narrowing the distance between original and reproduction can Eric overcome his belief that "I am in a constant collapse"(207). His fears of emptiness, lack and meaninglessness dominate the early sections of the book where his posteriority qualifies everything to do with his ontological status, so that "searching around inside my head, feeling through the black for any familiar shape. . . . it was all just cobwebs and shadows; I couldn't find myself in there either" (5). The existential blankness that substitutes for a core leads to the anxious "It isn't coming back to me. I don't know any of this at all" (4), a cry that focalises interiority as a presupposed point of orientation. Robbed of these coordinates, Eric tries, like Remainder's narrator, to reconstruct memory bridges to his physical surroundings, striving to reconnect with the object world as if it contains an immanence of remembered attachment:

I started off gently in the living room, picking things up, looking at them, trying to form some sort of connection; taking the time to read the title of every book in the bookcase, swapping a few around so the existing order became my random order; going through the papers in the magazine rack; getting on my knees and looking at the wires coming out of the back of the TV and at the dust and chips on the skirting boards. Trying to get intimate, make the space familiar from every angle. (19-20)

Material reality provides him with no empathic feedback and he is left pressed up against the door of an inexplicably locked room in his house, dislocated as much from the idea of himself as from any physical link to a self-identity. His severance from the narrative of selfhood begs questions of being, but more insistently, it begs questions of knowing, and it is these elusive epistemological issues that drive the novel in search of answers. While earlier, I established that McCarthy's narrator understands his authenticity through his relation to space, it is clear for Eric that the restoration of a unifying narrative is the only path to reconnecting with his former, more authentic, self.

Recovering the grail of authenticity demands a quest in search of Trey Fidorous, but what must be reiterated at this point is that this quest supposes the givenness of a self-congruent identity; 
though lost, there is always the possibility that it can be refound. This suggests that we are working within a biological paradigm of authenticity, and there are numerous metaphors of containment, immanence, storage, and isolation to indicate Hall's commitment to such a model. The chimera of spirit is embodied, for example, in the two rooms that Eric regards as offering answers to his many questions: the locked room in his house and the first Eric's room in Fidorous' paper burrow. These spaces initially seem to offer the prospect of resolution, but when he is finally able to access them, all they present him with are series of codes that need to be interpreted, and can thus only be read as epistemological deferrals. Deferral is, of course, generically structural to the quest narrative, but it is also fundamental to the novel's hermeneutic play through the QWERTY code in which the Light Bulb Fragment is couched. This code, which seems to hide the secret of the first Eric's disappearance, is based on the multiple combinations of proximate letters on a computer keyboard, and, given that any letter in the code has eight possible variations, meaning can only be gleaned through a tortuous series of deferrals and refinements based on cumulative sense making. As the code explains: "clean text cannot be constructed at the level of the individual letter. Possible translations must be constructed at word level, re-evaluated at sentence level and refined at paragraph level" (75). Once this outer encryption is resolved, a secondary deferral takes place as another code is plotted within QWERTY. The deferral of information leads ultimately to the deferral of narrative and the truth about the first Eric is never fully divulged.

The provisional status of encoded information extends to the novel's conceptualisation of disembodied identity. The opening paragraphs describing Eric's return to consciousness are dominated by the dissociation of his mind and body: he speaks about "the engines and drivers that keep the human machine functioning at a mechanical level" trip-switching to bring him back to "emergency manual override" (4). Later in the novel he laments feeling "so fucking tired of endless hours of doing my shitty best to cling my component parts together as a human being" (99), another construction that belies the idea of a ghost in this particular machine. This is in evidence again when Eric contemplates how the cycle of cell growth and death renders the body a site of continuous change, refuting at the molecular level the notion of contiguity that underlies the biological metaphor of authenticity. Rather than envisioning the human body as greater than the sum of its parts, The Raw Shark Texts dismantles it to reveal the mechanisms-organic, but programed nonetheless-that configure the human shape. Those mechanisms are little more than encoded information that, like the text's literary codes, depend on 
adjacent components for meaning and order: in themselves they are freestanding memes. This is brought into sharp focus during Eric's confrontation with Mr Nobody, whose name gestures toward his lack of corporeal being, and who literally begins to deliquesce once the pills that he takes to maintain his form begin to lose effectiveness. When Eric later examines Nobody's belongings, he discovers bottles containing the synthesised elements of a personality: "STYLE. EXTRAPOLATION. CONVICTION. FRIENDLY SMILE. POWERS OF PERSUASION ... CONCERN. SURPRISE. SUSPICION. DIGNITY" (177). Nobody is the quintessence of externality, but his immateriality is exemplary of Hall's fear of the human being's status as a core-less performance. After all, as Eric remarks: "A concept wrapped in skin and chemicals. . . . That sounds like a human being to me" (178).

What I am arguing, therefore, is that although the novel seems to favor the notion of the authentic self as a focus of desire, it also presents a radical skepticism to the very idea of any part of that self being internally reliable or integral.The mythology of authenticity aside, the self in the age of mass mediation and communication is indistinguishable from, and completely reliant on, the technological code it uses to articulate its presence in the material world. The Raw Shark Texts may be a paean for the interiorised humanist spirit, but there is a recognition that this is a fantasy in an era of mass informational transfer; the subject exists increasingly as a node on a network, and while that might not supplant the desire for authenticity and distinction, it does suggest that identity has become little more than programed software, the body simply a device for storing and transmitting code. This cyborg tendency is expressed most clearly in the megalomaniacal supra-subjectivity of Mycroft Ward. Ward, the novel's nemesis and generator of the Thought Shark that pursues Eric, is the ultimate example of a human being understood as a computer program-he is software endlessly reduplicated into human hardware. Originating as a means of cheating decay and death, Ward's project is to transmit his identity into the body of another by duplicating the building blocks of consciousness. This aspiration soon encompasses several bodies and, eventually, in the age of computerised interconnectivity, innumerable participants. The system he has created for his immortality has to replicate itself for "the irresistible urge to survive led to an equally irresistible urge to grow" (203). Formatted as a form of aggressive personality virus that sustains itself on the thought processes of others and feeds back useful information to the central "server," Mycroft Ward is able, as a result of constant technologized informational transfer, to grow itself exponentially, perpetually looping back, reinforcing itself and resisting disintegration. The voracious insatiability of Ward's viral immortality 
begs the question of whether the cloning of personality into endless, contiguous thought systems represents the apotheosis of an authentic identity-infinitely digitisable, replicable, and sharable-or whether it is the ultimate destruction of the notion of identity as an owned and private singularity. Where human identity is inextricably tied to human time-that is, it relies on time to evolve and develop, for skills to manifest themselves and be perfected-the digital identity, or identity as software, is boundless because it abides by the logic of computer time and because the proliferation of simulacral identities can result in an unlimited and instantaneous proliferation in data production.

If human identity can be equated with encoded information that can be downloaded on a processing mainframe, then, the novel suggests, the concept of unique, embodied authenticity can only be regarded as a secondary effect. Much in The Raw Shark Texts points to the occlusion of the subject by the informational detritus that swamps them. The hermeneutic dependence of the narrative on textual precursors such as Frankenstein, House of Leaves, Casablanca, The Wizard of $\mathrm{Oz}$, The Matrix and, Jaws mirrors, on a macro level, the routine enacting of familiar fictional scenarios by the novel's players. Structurally and imagistically, there is a recognizability to everything that occurs in the novel that speaks to its interest not only in textual recycling, but also the endless circuitry of cultural information. All the characters are types, but more importantly, they are nodes in a representational feedback loop that they perpetuate and through which they inscribe themselves. Even without having been subsumed by the Ward virus, they continuously cycle data as part of their conception of themselves as individuals. To some degree, Hall is playing here with the model of self-positing, but importantly there is the recognition that the experiences that are to be shaped are always already valenced within other representational orders and thus speak less to self-overcoming through aesthetic discrimination than to the human identity as a conduit for social and cultural traffic.

Hall's intervention on self-posited authenticity centers particularly on the surfeit of information that characterizes the digital age. In a moment of heavy symbolic resonance, Eric observes a rain-swollen river bursting its banks and rendering the surrounding countryside a seething mass:

Everything beyond the gateposts was furious: a river gone gigantic and deformed and crazy, banks burst and out on a greedy, rolling brown rampage. The size and force of it overloaded me, made me feel sick and dizzy. A too muchness. . . . No boundaries. The river was here reaching and grabbing and actually pulling at my feet and calves with a 
beautiful, mindless ache. A willpower in pressure. The river wanting to drag me off and smash me up and remake me as part of its pointless and stupidly powerful and passionate drive to change and obliteration. (98)

The vertiginous sensation generated in Eric by this indistinction destabilizes him because it is experienced as a sublime excess; the sheer surplus of the river momentarily robs his consciousness of the ability to judge the fixed from the flow. And the threat posed by this "too muchness" is palpable as his feet begin to give way under the current, a potent metaphorical articulation of the insignificance of the individual within the inexorable flood of data that characterizes contemporaneity. Within this technological sublime, the viability of the individual as authentically and harmoniously formed monad is, at best drastically reduced, and at worst, untenable. For all his melancholic wistfulness for the ghost in the machine, the irreducible and time-transcending self, Hall ultimately regards such conceptions as a romantic ideal in an age where the human has become little more than a fleshly interface for the free circling of data. Under such conditions, the notion of psychological coherence and authenticity are unsustainable and the very idea of the novel as the preeminent literary form for expressing character development becomes compromised. The metafictional elements of The Raw Shark Texts-most notably the flick-book stylisation of the Thought Shark's attack-counterbalance the realist, psychodrama of Eric's mental breakdown, but as it moves toward its disconnected conclusion, culminating in pictorial clues to his fate, the idea of this novel as a Bildungsroman is finally discredited. Hall's point is that there can be no satisfying conclusion to Eric's search for his former self because the self as expressivist whole is a fantasy. We are thus intended to read the final pages of disarticulated evidence as suggestive, but fundamentally aporetic flotsam washed up from the wreckage of Eric's subjective breakdown.

Despite disavowing the concept of character development, Hall engineers the reader's sympathy for Eric in a way that cannot be said for Remainder's narrator. That connection should not, however, disguise the fact that The Raw Shark Texts is harsher in its estimation of the possibility of authenticity than McCarthy's. The conclusion that the subject is constituted predominantly from the outside is similar to McCarthy's portrayal of the self as an artistic self-construction. But there is a greater anxiety that the individual in no way controls that process - that the central constitution of the self has been taken over by technology. The aesthetic self-assembly project is thus not tenable in Hall's world because the ubiquity of multiply-used information so intimately infiltrates the idea of self before the project could begin. Thus, in some ways, Hall's thinking is more radical than McCarthy's, 
for where the latter believes that the self can form itself from a space of stasis, the former understands the movement of self-formation as directed by the energy of informational transfer. Ultimately, where McCarthy believes that both models of authenticity are possible, Hall is convinced that neither is.

Though both McCarthy and Hall are heavily influenced by the aesthetic and philosophical horizons of poststructuralist postmodernism, both reveal in their engagement with authenticity a nostalgia for a Romantic tradition that, for all its unfashionable assumptions about the self, cannot be entirely dismissed as outdated or unselfconscious. The resilience of the idea of authenticity, its reemergence as a fictional trope in the dog-days of postmodernist experimentalism, suggests a willingness to move the debates about subjective experience onto new terrain. While that terrain may initially appear to have already been fully covered, McCarthy and Hall are representatives of a widespread movement in contemporary British writing that tackles an antihumanist politics not through the return to traditional models of narrative realism and character development, but through combative amalgamation of discursive experimentalism, metaphysical reflection, and wit. That neither can wholeheartedly assert the return of the subject from its deconstructive exile is unimportant, but the fact that both attest to the value of the authentic as the cornerstone of subjectivity in the twenty-first century may well be a significant development in contemporary literary studies.

\section{Note}

1. For comprehensive discussion of the philosophical history of authenticity see: Golomb, Guignon, Taylor (Ethics), and Trilling.

\section{Works Cited}

Badiou, Alain. The Century. Cambridge: Polity Press, 2007.

Boyle, David. Authenticity: Brands, Fakes, Spin and the Lust for Real Life. London: Harper, 2004.

Connor, Steven. "Introduction."The Cambridge Companion to Postmodernism. Ed. Steven Connor. Cambridge: Cambridge UP, 2004. 1-19.

Critchley, Simon. Ethics-Politics-Subjectivity: Essays on Derrida, Levinas and Contemporary French Thought. London: Verso, 1999.

Ferrara, Alessandro. Reflective Authenticity: Rethinking the Project of Modernity. London: Routledge, 1998. 
476 Authenticity in Post-2000 British Fiction

Golomb, Jacob. In Search of Authenticity: From Kierkegaard to Camus. London: Routledge, 1995.

Guignon, Charles. On Being Authentic. London: Routledge, 2004.

Hall, Steven. The Raw Shark Texts. Edinburgh: Canongate, 2007.

McCarthy, Tom. Remainder. London: Alma Books, 2007.

Schwenger, Peter. "The State of Inauthenticity." triplecanopy. Web. 11 Mar.2011.

Shields, David. Reality Hunger: A Manifesto. London: Hamish, 2010.

Taylor, Charles. The Ethics of Authenticity. Cambridge: Harvard UP, 1991. . A Secular Age. Cambridge: Harvard UP, 2007.

Trilling, Lionel. Sincerity and Authenticity. Cambridge: Harvard UP, 1971.

Williams, Bernard. Truth and Truthfulness. Princeton: Princeton UP, 2002. 